\title{
Relating patenting and peer-review publications: an extended perspective on the vascular health and risk management literature
}

This article was published in the following Dove Press journal:

Vascular Health and Risk Management

I5 April 201 I

Number of times this article has been viewed

\author{
Hermann AM Mucke \\ HM Pharma Consultancy, \\ Vienna, Austria
}

\begin{abstract}
Purpose: This investigation identifies patent applications published under the international Patent Convention Treaty between July 2010 and January 2011 in three significant fields of vascular risk management (arterial hypertension, atherosclerosis, and aneurysms) and investigates whether the inventors have also published peer reviewed papers directly describing their claimed invention.

Results: Out of only 48 patent documents that specifically addressed at least one of the abovementioned fields, 15 had immediate companion papers of which 13 were published earlier than the corresponding patent applications; the majority of these papers were published by noncorporate patentees. Although the majority of patent applications (30 documents) had at least one corporate assignee, 18 came from academic environments. As expected, medical devices dominated in the aneurysm segment while pharmacology dominated hypertension and atherosclerosis.

Conclusion: Although information related to hypertension, atherosclerosis, or aneurysms that was claimed in international patent applications reached the public quicker through the corresponding peer review document if one was published, more than two-thirds of the patent applications had no such companion paper in a scientific journal. The patent literature, which is freely available online as full text, offers information to scientists and developers in the fields of vascular risk management that is not available from the peer reviewed literature.
\end{abstract}

Keywords: hypertension, atherosclerosis, aneurysm, patents as topic, publishing

\section{Introduction}

There is no shortage of published information in the field of vascular risk management. In mid-February 2011, a PubMed search with the stringent term combination "blood vessels" [MeSH Terms] AND "risk management" [MeSH Terms] returned 3,603 hits, of which 535 had been published in 2010 or later; 600 were freely available as full text. These figures probably capture the majority of the PubMed-listed papers which have some degree of focus on vascular risk management, although an exact assessment of indexing precision is impossible because there is no single "correct" way to index a biomedical paper. (The current indexing practice in PubMed is a combination of MeSH terms provided by authors and those assigned by experienced human indexers at the National Library of Medicine, with algorithmic assistance).

However, neither the scientific journals that are included in the PubMed database nor the peer reviewed academic literature as a whole constitute a full representation of the public biomedical knowledge. A vast amount of information is published in the form of patent applications which are not peer reviewed according to scientific
HM Pharma Consultancy, Hutengasse 69

Vienna II60, Austria

Tel +43664 I0l 012 I

Fax +4366477101 0121

Email office@hmpharmacon.com 
criteria, but instead by a patent examiner. Moreover, the motivations for filing a patent application and for submitting a manuscript for publication in a scientific journal differ substantially: while a paper is intended to offer data that allow new insights, a patent application is filed based on the expectation that the invention claimed therein could have practical applications within the next few years. This endows the "patent information universe" with an application-driven perspective instead of a science-oriented one, and therefore the patent record can potentially offer a very different perspective on new developments.

The concepts of "novelty", "obviousness", and "inventive content" are of central importance in patenting but their meaning in the framework of intellectual property is quite different from the way academic research commonly interprets them; rather, these terms are applied in a strictly defined legalistic fashion. For example, combining a particular antihypertonic drug and a particular diuretic can have "novelty", even though members of the antihypertonic and diuretic drug classes have been combined for decades to treat hypertonia synergistically. The only proviso is that the particular combination being claimed as new has not been explicitly described prior to the filing date of the patent application (the priority date) in a fashion that makes it - in principle - accessible to the public, even if it has not been published in the academic sense. Even if the particular combination of drug species has been described earlier as being effective in treating hypertonia, a ratio between the compounds (or a dose) that is outside the previously described range can suffice for novelty. To carry the example further, "obviousness" is not defined by what a research cardiologist would view, but rather by what the "average knowledgeable person in the general field" (in this case, a pharmacologist with no research and development ambitions) could deduce by combining facts reported in the public "prior art" - without doing any experimental work.

On the other hand, any publicly available reference that predates the priority date of the patent application and describes the exact content of the claimed invention will negate novelty (and might create obviousness even if the description is not exact), and for this it does not have to appear in the academic or patent literature. For anybody who wants to have his or her work represented in both the academic and the intellectual property universe, it is essential to file the patent application before submitting the manuscript to a journal or making a congress presentation.

Using a comprehensive database of ophthalmological patent applications we have already reported case studies that demonstrate how patents can either anticipate the appearance of information in the peer review literature, or else can contain information that is never published in scientific journals. ${ }^{1}$ However, no systematic investigation had been undertaken at this time concerning whether inventions claimed in patent applications are also reported in the peer review literature. Such analyses of paired papers and patents in medical sciences are extremely scarce, and have mainly focused on the suspected restrictive influence of patenting on the dissemination of scientific information. ${ }^{2-4}$ The present paper reports a pilot study that analyzes the most recent international patent application record in three major fields of relevance for vascular risk management (arterial hypertension, atherosclerosis, and aneurysms), and relates this information to the peer review record as represented in the United States (US) National Library of Medicine's PubMed literature database.

\section{Materials and methods}

The World Intellectual Property Organization's PatentScope database ${ }^{5}$ was searched for the keyword terms "hypertension", "atherosclerosis", and "aneurysm" using date delimiters July 1, 2010 and January 31, 2011 and ignoring patent classification codes. Retrieved intellectual property documents were examined for their actual specific content concerning the above subjects; documents that named these conditions without specifically dealing with the subject matter were discarded. For example, documents that actually claimed drugs for treating diabetes and addressed hypertension and/or atherosclerosis only as diabetic complications were omitted from consideration, as were documents claiming drugs for dyslipidemia that named atherosclerosis. Also, documents that referred only to new crystal forms or other minor physical modifications to known active agents were omitted, while documents claiming innovative new formulations were included.

For each identified patent document, PubMed was searched for papers published from the patent document priority date onward and naming at least one of the inventors as an author. If the patent content suggested MeSH terms or free-text keywords, an additional search was conducted based on these terms. PubMed hits were then examined based on their abstracts (and full texts if available) to identify "companion papers" to the respective patent documents. A peer review paper was considered a companion paper if it had at least one inventor as an author, and captured the scientific and/or technical essence of the patent document. (Note that a peer review paper with a content largely identical to that of a patent that were published prior to the patent's 
filing date would invalidate the patent, therefore extending the PubMed search to earlier periods was not considered meaningful).

\section{Results}

Tables 1-3 present the key data of the identified international patent applications, and relate them to their companion peer review papers.

Hypertension: Of the 26 documents identified, 19 came from 16 different companies while seven had been filed by universities, hospitals, or foundations. The great majority (21 documents) concerned themselves with pharmaceuticals, while the remaining five dealt with biomarkers, surgical methods, or model algorithms. Only seven patent applications had direct peer review equivalents.

Atherosclerosis: Only eight patent applications were identified, with an even distribution between public and private assignees; six concerned pharmacological treatments; four had companion papers.

Aneurysm: Fourteen international patent documents, also with assignees evenly distributed between the corporate and noncorporate domains, were published during the period covered by our investigation; four had peer review equivalents. With the exception of three submissions claiming diagnostics, all were concerned with repair and stabilization devices. Five documents focused on cerebral aneurysms.

In total, 15 out of 48 patent applications had companion papers and 30 had at least one corporate assignee. Of the 15 patent-paper pairs, nine were published by academic or foundation inventors while six came from corporate inventors.

A closer look at the publication dates revealed that in all but two of those cases where a companion peer review paper had been published, it had appeared in print earlier than the corresponding patent document. This became even more pronounced if electronic publications ahead of print were included in the consideration (data not shown). Therefore a strong dichotomy resulted: while for the majority of patents the information was not available in peer review format at all, those cases where the information was also published in peer review journals tended to reach the public earlier in their peer reviewed versions. In several cases the paper preceded the corresponding patent by a year or more.

\section{Discussion}

Patent documents are very different from scientific journal papers in terms of intent, semantics, pre-publication critique, and publishing policy. The primary purpose of submitting a manuscript to an academic journal is to communicate new scientific data and information concisely to a specialized audience of peers. At least two of these peers will anonymously review the manuscript and decide its fate according to the commonly accepted criteria of the scientific community.

In contrast, a patent is filed with the perspective of securing exclusivity of use with respect to future commercial applications and to strategically preserve the inventors' and assignees' competitive edge. The requirement for legally explicit statements frequently leads to the use of language that is considered repetitive, redundant, or outright trivial by the average scientist working in the respective field. Review is by a single, personally identified examiner who is not necessarily an expert in the particular field, and who conducts the review according to legally defined criteria without attempting an assessment of feasibility (such as, for example, whether a particular vascular repair device would make sense in clinical practice). Regardless of the result of this examination, every patent document is published within about 18 months of its filing date unless the submission is retracted.

Virtually every single one of these features of a patent document runs counter to what academic researchers in the life sciences or in medicine expect from a published paper. As a result, life scientists frequently ignore patents while researchers working in technical, engineering, or software development fields traditionally value them highly.

This analysis of patenting versus peer-review publishing in three major fields of vascular risk management shows that disregarding published patent documents as a source of novel information can severely limit researchers' knowledge: 33 out of 48 documents had no direct equivalent in the peer review literature. Interestingly, this lack of matches was most pronounced in the field of hypertension which, as we had expected, had the most patent documents. However, there were a surprisingly low number of relevant patent documents identified overall so that conducting an actual comparative analysis for each field would not have been meaningful.

The analysis shows a dominance of corporate over academic and nonprofit organization assignees, however, the dominance is a relatively slight one $(63 \%)$. The present investigation did not involve direct comparison with equivalent earlier periods, but analyses that are available for US patents show that allowing US universities to claim title to inventions that had been made with federal funding have dramatically increased academic representation in 
Table I International patent applications concerning arterial hypertension, July 2010 to January 20 I I

\begin{tabular}{|c|c|c|c|c|}
\hline Patent number & $\begin{array}{l}\text { Assignee and } \\
\text { country }\end{array}$ & Subject & Published & $\begin{array}{l}\text { Companion } \\
\text { paper }\end{array}$ \\
\hline WO/20II/00800I & CJ Cheiljedang (KR) & $\begin{array}{l}\text { Antihypertensive composition } \\
\text { containing a ginsenosides enriched } \\
\text { fraction of ginseng extract }\end{array}$ & January 20, 2011 & None \\
\hline $\begin{array}{l}\text { WO/20I I/004040 } \\
\text { WO/20I I/004038 }\end{array}$ & $\begin{array}{l}\text { Universidad de Sevilla } \\
\text { (ES) }\end{array}$ & $\begin{array}{l}\text { Captopril or L-carnitine for controlling } \\
\text { the cardiac inflammatory process that } \\
\text { accompanies arterial hypertension }\end{array}$ & January 13,2011 & $\begin{array}{l}\text { J Inflamm (Lond). 2010;7:2I } \\
\text { and J Physiol Biochem. } \\
2010 ; 66(2): 127-136\end{array}$ \\
\hline WO/2010/I5092I & Teijin Pharma (JP) & $\begin{array}{l}\text { A 2-phenylthiazole agent for } \\
\text { hypertension or high-normal } \\
\text { blood pressure }\end{array}$ & December 29, 2010 & None \\
\hline WO/20I0/I484II & Entelos (US) & $\begin{array}{l}\text { Novel computer models of } \\
\text { hypertension comprising a renin- } \\
\text { angiotensin-aldosterone system } \\
\text { (RAAS) pathway module, a renal } \\
\text { function module, and a blood } \\
\text { pressure regulation module }\end{array}$ & December 23, 2010 & None \\
\hline WO/20I0/I4655I & $\begin{array}{l}\text { Ranbaxy Laboratories } \\
\text { (IN) }\end{array}$ & $\begin{array}{l}\text { Orally disintegrating compositions } \\
\text { comprising angiotensin II receptor } \\
\text { antagonists for hypertensive crisis }\end{array}$ & December 23, 2010 & None \\
\hline WO/2010/I43059 & $\begin{array}{l}\text { Generex Pharmaceuticals } \\
\text { (CA) }\end{array}$ & $\begin{array}{l}\text { Geum japonicum plant extracts for } \\
\text { preventing or treating hypertension }\end{array}$ & December 16, 2010 & None \\
\hline WO/20I0/I42794 & $\begin{array}{l}\text { Bios International } \\
\text { (IT) }\end{array}$ & $\begin{array}{l}\text { Non-enzymatic in vitro method for } \\
\text { detecting gP } 9 \text { | phox as a marker } \\
\text { of oxidative stress, including } \\
\text { hypertension, atherosclerosis, } \\
\text { cardiac hypertophy, and stroke }\end{array}$ & December 16, 2010 & None \\
\hline WO/2010/I37336 & Kowa (JP) & $\begin{array}{l}\text { Alpha-phenoxybenzeneacetic acid } \\
\text { derivatives that are angiotensin II } \\
\text { receptor antagonists and PPARgamma } \\
\text { agonists, for hypertension and } \\
\text { metabolic syndrome }\end{array}$ & December 2, 2010 & None \\
\hline WO/20I0/I 29379 & $\begin{array}{l}\text { Merck Sharpe and } \\
\text { Dohme (US) }\end{array}$ & $\begin{array}{l}\text { Inhibitors of the Renal Outer } \\
\text { Medullary Potassium (ROMK) channel } \\
\text { (Kirl.I) with diuretic and natriuretic } \\
\text { action for hypertension and chronic } \\
\text { and acute heart failure }\end{array}$ & November II, 2010 & None \\
\hline WO/20I0/I 27096 & $\begin{array}{l}\text { Midwestern University } \\
\text { (US) }\end{array}$ & $\begin{array}{l}\text { Centhaquin and related adrenergic } \\
\text { agents for treating hypertension, pain, } \\
\text { and resuscitative hemorrhagic shock }\end{array}$ & November 4, 2010 & None \\
\hline WO/20I0/I2420I & $\begin{array}{l}\text { Invasc Therapeutics } \\
\text { (US) }\end{array}$ & $\begin{array}{l}\text { Methylenedioxyphenyl ferulate, } \\
\text { ferulylproline, and derivatives thereof as } \\
\text { myeloperoxidase inhibitors and } \\
\text { vasodilators for cardiovascular diseases }\end{array}$ & October 28, 2010 & None \\
\hline $\mathrm{WO} / 2010 / \mathrm{I} 24120$ & $\begin{array}{l}\text { Mercator Medsystems } \\
\text { (US) }\end{array}$ & $\begin{array}{l}\text { Minimally invasive surgery with local } \\
\text { application of guanethidine into the } \\
\text { adventitia to reduce the activity of the } \\
\text { sympathetic nerves surrounding the } \\
\text { renal artery, for the treatment of } \\
\text { renal and arterial hypertension }\end{array}$ & October 28, 2010 & None \\
\hline WO/20I0/II 9700 & Kowa (JP) & $\begin{array}{l}\text { Dual angiotensin II receptor antagonist } \\
\text { and PPARgamma agonist, for } \\
\text { hypertension and metabolic } \\
\text { syndrome }\end{array}$ & October 21, 2010 & None \\
\hline WO/2010/II6282 & Pfizer (US) & $\begin{array}{l}\text { 4,5-Dihydro-IH-pyrazole } \\
\text { mineralocorticoid receptor } \\
\text { antagonists for diabetic nephropathy } \\
\text { and hypertension }\end{array}$ & October 14,2010 & $\begin{array}{l}\text { J Med Chem. } \\
\text { 2010;53(I6):5979-6002 }\end{array}$ \\
\hline
\end{tabular}


Table I (Continued)

\begin{tabular}{|c|c|c|c|c|}
\hline Patent number & $\begin{array}{l}\text { Assignee and } \\
\text { country }\end{array}$ & Subject & Published & $\begin{array}{l}\text { Companion } \\
\text { paper }\end{array}$ \\
\hline WO/2010/I0472I & Eli Lilly (US) & $\begin{array}{l}\text { 5-((E)-(3-fluorodibenzo[b,e]oxepin- } \\
\text { I II(6H)-ylidene)methyl)-I-((7R,8aR)- } \\
\text { hexahydro-I H-pyrrolo [2,I-c][I,4] } \\
\text { oxazin-7-yl)-I H-benzo[d]imidazol- } \\
\text { 2(3H)-one, a mineralocorticoid } \\
\text { receptor antagonist for kidney disease, } \\
\text { hypertension, and heart failure }\end{array}$ & September 16, 2010 & None \\
\hline WO/2010/I04646 & $\begin{array}{l}\text { Scott and White } \\
\text { Memorial Hospital (US) }\end{array}$ & $\begin{array}{l}\text { Simultaneous measurement of } \\
\text { marinobufagenin and angiotensinogen } \\
\text { in urine to differentiate volume } \\
\text { extension and vasoconstrictive forms } \\
\text { of hypertension }\end{array}$ & September 16, 2010 & None \\
\hline WO/2010/099054 & $\begin{array}{l}\text { Merck Sharpe and } \\
\text { Dohme (US) }\end{array}$ & $\begin{array}{l}\text { Soluble guanylate cyclase activators } \\
\text { for endothelial dysfunction, } \\
\text { atherosclerosis hypertension, } \\
\text { and heart disease }\end{array}$ & September 2, 2010 & None \\
\hline WO/2010/096677 & $\begin{array}{l}\text { Invasc Therapeutics } \\
\text { (US) }\end{array}$ & $\begin{array}{l}\text { Dinitroso-derivatives of dihydrolipoic } \\
\text { acid for hypertension, myocardial } \\
\text { infarction, stroke, atherosclerosis ect. }\end{array}$ & August 26, 2010 & None \\
\hline WO/2010/095462 & Kowa (JP) & $\begin{array}{l}\text { 3-(5-Akoxypyrimidine-2-yl) pyrimidine- } \\
4(3 \mathrm{H}) \text {-one dual angiotensin II receptor } \\
\text { antagonist and PPARgamma agonist, for } \\
\text { hypertension and metabolic syndrome }\end{array}$ & August 26, 2010 & None \\
\hline WO/20I0/0928II & Nihon University (JP) & $\begin{array}{l}\text { Biphenylcarboxamide compound for } \\
\text { hypertension }\end{array}$ & August 19,2010 & None \\
\hline WO/2010/088279 & Cardiomems (US) & $\begin{array}{l}\text { Wearable wireless blood pressure } \\
\text { monitoring system with implanted } \\
\text { sensor }\end{array}$ & August 5, 2010 & None \\
\hline WO/20I0/08423I & $\begin{array}{l}\text { Fundació Institut de } \\
\text { Recerca de L’Hospital } \\
\text { Universitari Vall } \\
\text { d’Hebron (ES) }\end{array}$ & $\begin{array}{l}\text { Kidney androgen-regulated protein } \\
(\mathrm{KAP}) \text { gene expression in renal tissue, } \\
\text { for models to evaluate antihypertensive } \\
\text { compounds }\end{array}$ & July 29,2010 & $\begin{array}{l}\text { Circulation. } \\
\text { 2009;।19(14):1908-1917 }\end{array}$ \\
\hline WO/20I0/082367 & Kikkoman (JP) & $\begin{array}{l}\text { Orally bioavailable angiotensin- } \\
\text { converting enzyme (ACE)-inhibiting } \\
\text { di- and tripeptides }\end{array}$ & July 22,2010 & $\begin{array}{l}\text { J Agric Food Chem. } \\
2010 ; 58(2): 821-827\end{array}$ \\
\hline WO/2010/080I83 & $\begin{array}{l}\text { University of Columbia } \\
\text { (US) }\end{array}$ & $\begin{array}{l}\text { Vasodilatory and anti-inflammatory } \\
\text { soluble epoxide hydrolase inhibitors } \\
\text { to treat hypertension }\end{array}$ & July I5, 2010 & $\begin{array}{l}\text { Bioorg Med Chem Lett. } \\
\text { 2009;19(8):2354-2359 }\end{array}$ \\
\hline WO/2010/078624 & Vegenics (AU) & $\begin{array}{l}\text { Vascular endothelial growth factor } \\
\text { (VEGF) C and D products for } \\
\text { hypertension }\end{array}$ & July 15,2010 & $\begin{array}{l}\text { Nat Med. } \\
\text { 2009;।5(5):545-552 }\end{array}$ \\
\hline
\end{tabular}

patenting during the following two decades. ${ }^{6}$ An analysis of the patenting and publishing data of 395 academic inventors from five major universities in Taiwan from 2002 to 2006 suggested that patenting might increase the number and quality of papers published by these inventors. ${ }^{7}$

Although the absolute numbers are too low for actual statistics, the available data suggest that corporate inventors are less likely to publish their patented findings in scientific journals than nonprofit inventors. This was expected, since peer-review publishing is firmly rooted in academic culture while the standing of corporate scientists in the life sciences, or their companies, is not usually measured by such criteria. Patents are deemed far more important in this environment. If a 1987 analysis of 17 US pharmaceutical companies has demonstrated their patent data to represent an excellent indicator of overall corporate technological strength, ${ }^{8}$ there is little reason to assume that this situation has changed fundamentally. In addition, most patents that claim incremental improvements over the prior art (eg, a new orally disintegrating tablet formulation for a particular compound, or a variation in the design of a vascular repair device) would not meet the criteria of "novelty" and "non-obviousness" 
Table 2 International patent applications concerning atherosclerosis, July 2010 to January 20 I I (excluding antihyperlipidemic, antidiabetic, and nonspecific anti-inflammatory drugs)

\begin{tabular}{|c|c|c|c|c|}
\hline Patent number & Assignee and country & Subject & Published & Companion paper \\
\hline WO/20II/005608 & $\begin{array}{l}\text { Merck Sharpe and Dohme } \\
\text { (US) }\end{array}$ & $\begin{array}{l}\text { Cyclohexyl sulfonamide platelet- } \\
\text { activating factor (PAF) receptor } \\
\text { antagonists }\end{array}$ & January $13,201 \mid$ & None \\
\hline WO/2010/I 33662 & INSERM (FR) & $\begin{array}{l}\text { Interleukin- } 17 \text { polypeptides for the } \\
\text { prevention and treatment of } \\
\text { atherosclerosis }\end{array}$ & November 25, 2010 & $\begin{array}{l}\text { Curr Opin Lipidol. 20 I 0;2I (5): } \\
404-408\end{array}$ \\
\hline $\mathrm{WO} / 2010 / 126967$ & $\begin{array}{l}\text { Boehringer Ingelheim (DE); } \\
\text { New York University (US) }\end{array}$ & $\begin{array}{l}\text { Ex-vivo treatment of blood with } \\
\text { protein kinase C-theta inhibitors } \\
\text { for immunological diseases and } \\
\text { atherosclerosis }\end{array}$ & November 4, 2010 & $\begin{array}{l}\text { Science. 2010;328(5976): } \\
372-376\end{array}$ \\
\hline WO/2010/I084I9 & $\begin{array}{l}\text { Chinese Academy of } \\
\text { Medical Sciences (CN) }\end{array}$ & $\begin{array}{l}\text { PON gene cluster to promote } \\
\text { stability of atherosclerotic plaques }\end{array}$ & September 30,2010 & $\begin{array}{l}\text { Circ Res. 2009; 104(I0): } \\
\text { II60-II68 }\end{array}$ \\
\hline WO/2010/I05285 & $\begin{array}{l}\text { Heart Research Institute } \\
\text { (AU) }\end{array}$ & $\begin{array}{l}\text { Testing for atherosclerosis or a } \\
\text { predisposition thereto, based on } \\
\text { monocyte-derived endothelial cells }\end{array}$ & September 23, 2010 & None \\
\hline WO/2010/088455 & General Hospital Corp. & $\begin{array}{l}\text { Cromolyn analogs to image and } \\
\text { treat atherosclerotic plaques }\end{array}$ & August 5,2010 & None \\
\hline WO/2010/079I6I & INSERM (FR) & $\begin{array}{l}\text { B cell depleting agent for the } \\
\text { prevention or treatment of } \\
\text { atherosclerosis }\end{array}$ & July 15,2010 & $\begin{array}{l}\text { J Exp Med. 20।0;207(8): } \\
\text { I579-I578 }\end{array}$ \\
\hline WO/2010/077624 & $\begin{array}{l}\text { Merck Sharpe and Dohme } \\
\text { (US) }\end{array}$ & $\begin{array}{l}\text { Biaryl carboxamide PAF receptor } \\
\text { antagonists }\end{array}$ & July 8,2010 & None \\
\hline
\end{tabular}

that are commonly applied in academic peer review, even if the claimed improvements might be immediately applicable and useful. In this context, a lack of companion peer review papers does not indicate poor relevance of a patent.

A very limited number of investigations have been published that discuss selected aspects of patenting in the context of the vascular risk factors that are the subject of this investigation. ${ }^{9-11}$ While these are important reviews that illustrate certain aspects, no analysis had been previously undertaken to relate such patenting activity with conjoined peer-review publishing.

This pilot study obviously has several limitations. First, since the latest patents included in this analysis were published only three weeks prior to the time of writing, more delayed peer review companion papers might be published as time progresses. However, the two post-patent peer review papers that this analysis did reveal appeared within a few weeks of the corresponding patent. Therefore it seems unlikely that many more true companion papers will be published for the patents listed in Tables 1-3. The delays involved in PubMed indexing of some peer review journals, which can amount to several months, constitute a potentially more severe limitation of this analysis, which covers the most recent 7 months of patenting related to innovation in vascular risk management. Studies that extend over longer periods of patenting and publishing, or compare several periods, could eventually provide more insight.
The data that are available now allow the conclusion that international patent applications can offer valuable insights into new developments concerning vascular risk management which are not made available in academic peer-review publishing, at least not without a delay of many months which our limited study would not have consistently detected. This implies that systematic monitoring of the patent literature can potentially add a substantial amount of cutting edge information.

However, the obvious difficulty of the scientist having to negotiate the legalistic style and repetitive nature of patent jargon remains, as does the difficulty to identify relevant patents. While it has been argued that patent searching must become part of life science students' information literacy instruction, ${ }^{12}$ a more pragmatic and encompassing approach could be algorithmically mapping patents to $\mathrm{MeSH}$ codes, ${ }^{13}$ which would allow integrated searches that cover both PubMed and open access patent databases. Although algorithmic parsing of typical "patent jargon" into semantics that are familiar to research scientists is only a dimly perceived possibility at this time, ${ }^{14}$ text analysis has been able for some years to effectively identify innovative patents and provide ranking and mapping. ${ }^{15}$ For specialized applications such as the vascular risk management literature, expert systems might provide broadly deployable semi-automated solutions within the next few years. 
Table 3 International patent applications concerning aneurysms, July 2010 to January 2011

\begin{tabular}{|c|c|c|c|c|}
\hline Patent number & Assignee and country & Subject & Published & Companion paper \\
\hline WO/20I I/008906 & Mayo Foundation (US) & $\begin{array}{l}\text { Automatic detection of cerebral } \\
\text { aneurysms by assigning points of } \\
\text { interest to raw image data files }\end{array}$ & January $20,201 \mathrm{I}$ & $\begin{array}{l}\text { J Digit Imaging. 20I I;24(I): } \\
86-95\end{array}$ \\
\hline WO/20I I/007352 & $\begin{array}{l}\text { Yissum R\&D } \\
\text { (Univ. of Jerusalem) (IL) }\end{array}$ & $\begin{array}{l}\text { New endovascular aortic repair } \\
\text { technique using a flexible } \\
\text { endoprosthesis which stiffens at the } \\
\text { implanation site }\end{array}$ & January 20,2011 & None \\
\hline WO/20I0/I45703 & $\begin{array}{l}\text { GraftCraft i Göteborg } \\
A B(S E)\end{array}$ & $\begin{array}{l}\text { Endovascular device for repair of a } \\
\text { ruptured aneurysm, consisting of a } \\
\text { balloon with a channel extending } \\
\text { through it and a supporting blood- } \\
\text { permeable stent which remains in situ } \\
\text { for I-2 days postoperatively }\end{array}$ & December 23, 2010 & None \\
\hline WO/2010/I349/4 & University of Miami (US) & $\begin{array}{l}\text { Spherical helix coils with shape memory } \\
\text { to occlude cerebral aneurysms }\end{array}$ & November 25,2010 & $\begin{array}{l}\text { J Med Device. } \\
\text { 2009;3(4):41005* }\end{array}$ \\
\hline WO/20I0/I 29270 & $\begin{array}{l}\text { Shriners Hospitals for } \\
\text { Children; Pregon Health } \\
\text { and Science University (US) }\end{array}$ & $\begin{array}{l}\text { Immunoassays to monitor disease } \\
\text { progression in individuals with Marfan's } \\
\text { syndrome, aortic aneurysm, or } \\
\text { scleroderma based on the } \\
\text { concentration of circulating elastic fiber } \\
\text { and microfibril fragments (fibrillin } \\
\text { and fibulin) }\end{array}$ & November II, 2010 & None \\
\hline WO/20I0/I2738I & $\begin{array}{l}\text { James Cook University } \\
(\mathrm{AU})\end{array}$ & $\begin{array}{l}\text { Altering levels of components in the } \\
\text { kallikrein-kinin system to assist in } \\
\text { preventing or treating aneurysms }\end{array}$ & November II, 2010 & None \\
\hline WO/2010/I2391I & $\begin{array}{l}\text { Lake Region Medical, Inc. } \\
\text { (US) }\end{array}$ & $\begin{array}{l}\text { A tubular meshwork device with a } \\
\text { patch to occlude the the neck of the } \\
\text { aneurysm upon insertion, with exact } \\
\text { axial and rotational positioning through } \\
\text { a marker }\end{array}$ & October 28, 2010 & None \\
\hline WO/20I0/I2383I & $\begin{array}{l}\text { Chestnut Medical } \\
\text { Technologies, Inc. (US) }\end{array}$ & $\begin{array}{l}\text { An occluding device that can be used to } \\
\text { remodel an aneurysm within the vessel } \\
\text { by neck reconstruction or balloon } \\
\text { remodeling }\end{array}$ & October 28, 2010 & $\begin{array}{l}\text { Neurosurgery. 2009;64(4): } \\
632-642\end{array}$ \\
\hline WO/20I0/I 20926 & $\begin{array}{l}\text { Chestnut Medical } \\
\text { Technologies, Inc. (US) }\end{array}$ & $\begin{array}{l}\text { Occluding devices with adjustable } \\
\text { porosity for tortuous vessels, especially } \\
\text { of the neurovasculature, in proximity of } \\
\text { oxygen-demanding tissues }\end{array}$ & October 21,2010 & $\begin{array}{l}\text { Neurosurgery. 2009;64(4): } \\
632-642\end{array}$ \\
\hline WO/2010/II 2838 & $\begin{array}{l}\text { Barking Havering and } \\
\text { Redbridge Hospitals (UK) }\end{array}$ & $\begin{array}{l}\text { Multi-balloon catheter device for } \\
\text { occlusion of aneurysms, with some } \\
\text { balloons serving as deflectors for an } \\
\text { occluding agent }\end{array}$ & October 7, 2010 & None \\
\hline WO/2010/II0819 & $\begin{array}{l}\text { Arista Therapeutics, Inc. } \\
\text { (US) }\end{array}$ & $\begin{array}{l}\text { Improved implantable device } \\
\text { containing and light-emitting diode } \\
\text { (LED) matrix to internally irradiate } \\
\text { aneurysms }\end{array}$ & September 30,2010 & None \\
\hline WO/2010/08949I & A.L.N. (FR) & $\begin{array}{l}\text { Intravascular device for occluding } \\
\text { and aneurysm, consisting of a } \\
\text { longitudinal, partially planar mesh } \\
\text { skeleton covered with a film }\end{array}$ & August 12,2010 & None \\
\hline WO/2010/082026 & Isis Innovation Ltd. (UK) & $\begin{array}{l}\text { Stents for intracranial aneurysms, } \\
\text { consisting of linked plates or rings } \\
\text { arranged as a tube and deformable } \\
\text { between an expanded state and a } \\
\text { collapsed state }\end{array}$ & July 22,2010 & None \\
\hline WO/2010/076838 & Individual inventor (IT) & $\begin{array}{l}\text { Catheter for a transcaval approach to } \\
\text { an abdominal aneurysm }\end{array}$ & July 8,2010 & None \\
\hline
\end{tabular}

Note: *Same institution and subject, authors different from inventors. 


\section{Disclosure}

The author reports no conflicts of interest in this work.

\section{References}

1. Mucke HAM, Mucke P, Mucke E. International patenting in ophthalmology: an analysis of its structure and relevance for the development of drugs and diagnostics. Clin Ophthalmol. 2009;3: 103-109.

2. Murray F. Innovation as co-evolution of scientific and technological networks: exploring tissue engineering. Res Pol. 2002;31(8-9): 1389-1403.

3. Murray F, Stern S. Do formal intellectual property rights hinder the free flow of scientific knowledge? An empirical test of the anti-commons hypothesis. J Econ Behav Organ. 2007;63(4):648-687.

4. Huang KG, Murray FE. Does patent strategy shape the long-run supply of public knowledge? Evidence from human genetics. Acad Manage J. 2009;52(6):1193-1221.

5. World Intellectual Property Organization. PatentScope database. Available at: http://www.wipo.int/pctdb/en/. Accessed March 24, 2011.

6. Loise V, Stevens AJ. The Bayh-Dole Act turns 30. Sci Transl Med. 2010;2(52):52 $\mathrm{cm} 27$.

7. Chang YC, Yang PY, Tsai-Lin T. The impacts of academic patenting on paper publication: a quantity-quality examination. In: Proceedings of PICMET '10: Technology Management for Global Economic Growth (PICMET); 2010 July 18-22; Phuket, Thailand. 162-172.
8. Narin F, Noma E, Perry R. Patents as indicators of corporate technological strength. Res Pol. 1987;16(2-4):143-155.

9. Tulis DA. Methods for identifying cardiovascular agents: a review. Recent Pat Cardiovasc Drug Discov. 2006;1(1):47-56.

10. Feher G, Illes $Z$. Gene patents in the primary prevention of vascular diseases. Recent Pat DNA Gene Seq. 2008;2(3):164-171.

11. Viljoen A. New approaches in the diagnosis of atherosclerosis and treatment of cardiovascular disease. Recent Pat Cardiovasc Drug Discov. 2008;3(2):84-91.

12. MacMillan D. Patently obvious: the place for patents in information literacy in the sciences. Res Strategies. 2005;20(3):149-161.

13. Griffin TD, Boyer SK, Councill IG. Annotating patents with Medline MeSH codes via citation mapping. Adv Exp Med Biol. 2010;680: 737-744.

14. Parapatics P, Dittenbach M. Patent claim decomposition for improved information extraction. In: Proceeding of the 2nd International Workshop on Patent Information Retrieval (PaIR'09); 2009 November 2-6; Hong Kong, China. New York: ACM New York; 2009:33.

15. Hasan MA, Spangler WS. IBM research report RJ104102 (A0701-011): assessing patent value through advanced text analysis. January 17, 2007. Available at: http://domino.research.ibm.com/library/cyberdig. nsf/papers/D9A7DD04B21122B5852572680061BDF5/\$File/rj10402. pdf. Accessed March 24, 2011.
Vascular Health and Risk Management

\section{Publish your work in this journal}

Vascular Health and Risk Management is an international, peerreviewed journal of therapeutics and risk management, focusing on concise rapid reporting of clinical studies on the processes involved in the maintenance of vascular health; the monitoring, prevention and treatment of vascular disease and its sequelae; and the involvement of

\section{Dovepress}

metabolic disorders, particularly diabetes. This journal is indexed on PubMed Central and MedLine. The manuscript management system is completely online and includes a very quick and fair peer-review system, which is all easy to use. Visit http://www.dovepress.com/ testimonials.php to read real quotes from published authors. 